\title{
Intellectual Property Protection of Indigenous Peoples in Indonesia: Quo Vadis?
}

\author{
Anis Mashdurohatun ${ }^{1 *}$, Ariy Khaerudin ${ }^{1}$ and Teguh Prasetyo ${ }^{2}$ \\ 1. UNISSULA. Semarang-Indonesia \\ 2. UPH, Jakarta, Indonesia \\ *anism@unissula.ac.id
}

Published: 28/02/2020

How to cite:

Mashdurohatun, A., Khaerudin, A., Prasetyo, T. 2020. Intellectual Property Protection of Indigenous Peoples in Indonesia: Quo Vadis?. Sociological Jurisprudence Journal. Volume 3 Issue 1. Page 1 - 7. https://doi.org/10.22225/scj.3.1.1268.1-7

\begin{abstract}
Illicit used of intellectual property protection of indigenous peoples which are increasingly exploitative and leaving the existing values, and it's happen over the world. Paradox government need it for raw material in creative economic but there's no law to protect. The aim of this study is to describe dilemma of law patronage for Intellectual property of Indigenous People. Method for this study used library research. The values of justice in the use of traditional cultural expressions are carried out proportionally and balanced by harmonizing the values of individuals with communal values. Based on it ought to palladium with legal system that preserve behalf indigenous peoples in order to achieve legal objectives (Justice, certainty and expediency).
\end{abstract}

Keywords: IPR; Indigenous.

\section{INTRODUCTION}

Creative economy, based on ideas and innovations launched in Indonesia, is believed to be a pillar of the economy in the future. The raw material of the creative economy is the art of culture or the value of local wisdom which in the International system is called Expressions of Folklore (EoF)/TCEs (TCEs). There are a number of lucrative economic values after an economy based on natural resource exploitation. Then, the exploitation of TCEs began to derogatory and disrespectful with values contained therein.

Relation with economic value can be explain for example in the fashion world, such as usage includes hats, shirts and scarves inspired by Maasai Shuka - the traditional African blanket design in red and blue Maasai by the famous brand Luis Vuitton earns millions of dollars and ironically $80 \%$ of the Maasai people live below the line poverty without being able to enjoy the results of his intellectual creations (Young, 2017).

Lego Company had also been prosecuted for the use of the Maori and the Maori history of the people used in their computer game Lego "Bionicle" (Goodwin, 2013). It use of Māori words "was an unauthorized use of traditional names and language, and it was an inappropriate use. There had been no consultation, no prior informed consent. And it's a trivialization, especially when you are using names like Tohunga (Maori for priest)" (Lum-ho, 2013). Another example is the case of John Bulun Bulun \& Anor v R \& T Textiles Pty Ltd (1998) in the case of flash T-shirts using Aboriginal tribal Bark Painting "Magpie Geese and Water Lilies at the Waterhole" motifs (Hardie, 1998).

Reflecting on other countries' EBT as it was adapted into a film product called "Mulan". This story is taken from the Chinese folk legend "Hua Mulan" which was later adapted in the film industry by Disney in 1998. Disney adapted Chinese folklore "The Ballad of Mulan". This adaptation action was then by experts at China Professors Weimin Mo and Wenju Shen who accused Disney as having done a 
"bulldozer [that] rolls over the Chinese culture" by modifying the story and eliminating the cultural context of the story (Andersen, 2010). Tragically this film actually got a Golden Globe and Academy Award nomination and has generated \$ 303.4 million (Lee, 2015).

In Indonesia, the case of the use of traditional people's intellectual property was a case of the carving catalog "Jepara Harisson \& Gill Carving out a piece of History" how the carving motif which is a hereditary work of the Jepara community is personally recognized by Foreigners (Christopher Harisson) so that it prohibits other parties who will use the carving model in the furniture industry. In his opinion mentioned the work as a public domain (Kuncoro, 2010).

Another TCE violation can be found in the research by (Tama, 2017) stated that there was an abuse of the symbol of the Yogyakarta praja cihna in commercial goods, such as t-shirts. ] Another misuse Sunanate Surakarta TCEs has long been happening and out of attention of the government. The misuse which has left the palace's dignity can be found and considered normal by the community. For example, the Parang Batik motif which is a ban motif can be found in fashion products to be used as a base for footwear motifs. The misuse of Parang batik motif can be found in a fashion motif by celebrities, hotel ornaments, as well as ethnic makeup (Fimela, 2013).

TCEs as culture of indigenous people have communal rights that are owned by the community. The United Nations actually issued the draft United Nations Declaration on the Rights of Indigenous Peoples. But developed countries refused to sign. The reluctance of developed countries is essentially rejecting the collective rights of the people. This caused injustice because there was still a spirit of mastering other nations, which was another form of colonialism.

WIPO (World Intellectual Property Organization) and UNESCO (United Nation of Education Science and Culture Organization) raised protection against the use of TCEs in the provision draft for the protection of TCEs and traditional knowledge against misappropriation or misuse (World Intellectual Property Organization, 1985). In the law model, it is stated that there is an obligation for users or parties who utilize TCEs to provide benefit sharing by mentioning the indigenous people who own the traditional cultural expression.

However, Indonesia not yet adapted the model law in National Law. There are some problem with the law that can be protected the rights. Copyright Law not clearly state how to protect TCEs from used of it. Trademarks law as the finding study can't protect the symbol of TCEs. Sui Generis Law that can be protect TCEs until now still in the draft law. Unfortunately, the Draft not in the list of priority on Indonesia National Legislation Program on 2018.

\section{METHOD}

This study uses library research. Primary legal materials for this research are The Constitution of Indonesia and law related with folklore. Secondary legal materials include Books, journals and commentaries which discuss the law and reference tools (dictionaries and encyclopedias). The data was collected by examining the legal material which was then analysed with content analysis and qualitative technique and interpreted logically and systematically then drawn conclusion.

\section{III.RESULT AND DISCUSSION}

Folklore terminology in Merriam Webster's dictionary (Merriam Webster's, 1828) mentions it as 1: traditional customs, tales, sayings, dances, or art forms preserved among a people. In terminology, according to the Indonesian dictionary (KBBI), folklore is defined as 1 traditional customs and folklore which is passed down from generation to generation, but is not recorded; 2 traditional traditions of science and folklore that are not recorded; - oral folklore created, disseminated, and passed on in oral form (folk language, puzzles, folk poetry, folk prose stories, and folk songs); - not oral folklore created, disseminated, and passed on not in oral form (folk architecture, folk handicrafts, traditional clothing and jewelery, traditional medicines, traditional food and drink, signaling sounds, and traditional music).

The black law dictionary includes folklore in the definition of cultural property as Movable and immovable property that has cultural significance, whether in the nature of antiquities and monuments of a classical age or important modem items of fine arts, decorative arts, and architecture (Black's Law Dictionary, 2004). Some writers prefer the term cultural heritage, which more broadly includes 
intangible cultural things such as folklore, crafts, and skills.

WIPO give definition Traditional cultural expressions (TCEs), also called "expressions of folklore", may include music, dance, art, designs, names, signs and symbols, performances, ceremonies, architectural forms, handicrafts and narratives, or many other artistic or cultural expressions (World Intellectual Property Organization, 2008).

The definition of TCEs found in the explanation of Article 38 of Law No. 28/2014 on Copyright which states TCEs include one or a combination of expressions of textual verbal, music, motion, theatre, fine art and traditional ceremonies.

The concept of indigenous and tribal peoples was first introduced by Cornelius van Vollenhoven. Ter Haar as a student of Cornelius van Vollenhoven explored more deeply about indigenous and tribal peoples. Ter Haar gives the following meaning, customary law communities are organized groups of people, settling in a certain area, having their own power, and having their own wealth in the form of visible and invisible objects, where members of each unit experience life in society as a natural thing according to the nature of nature and none of the members have the mind or tendency to dissolve the bonds that have grown it or leave it in the sense of breaking away from that bond forever (Alting, 2010). Indigenous peoples show a close relationship in interpersonal relationships and the process of social interaction that occurs between humans, causing certain patterns that are called in a way (a uniform or customary of belonging within a social group (Nurtjahjo \& Fuad, 2010).

Close relationships are often referred to as fiduciary ties between indigenous peoples and cultural products known as folklore or TCEs and traditional knowledge. Because as a part of the inherited and hereditary nature, it gives the same rights as the owner. Beneficiary has ius habendi that is intended as the right to convert property into actual possession, while Ius disponendi is the right to instruct trustees to transfer ownership of property to parties determined by the beneficiary himself (Fuady, 2002).

Protection of TCEs has a long history since the Berne Convention on Copyrights up to a number of other conventions conducted by international bodies such as WIPO, UNESCO and WTO. TCEs in Berne Convention included in Article 15 (4) letters a and b of the work in which there is no author.

Tunis Model Law on Copyright Protection of the use of TCEs or folklore in the system of intellectual property rights has been pursued internationally. The background of the results of international negotiations under WIPO and UNESCO provides examples / models of protection to be regulated in the legal system in each Member State. Model rules that can serve as guidelines for effectively protecting all States. This Law Model is based on 2 basic things, namely the rules in this model are in accordance with the 1971 Berne Convention and the 1971 Universal Copyright Convention and the rules are adjusted to Roman and Anglo Saxon Law. In this law model also provides recognition of the protection of folklore. Its protection is considered the same as protection of copyright. For developing countries folklore is part of cultural heritage and vulnerable to economic exploitation.

At the regional level, ASEAN also discussed cooperation on traditional biblical expressions. TCEs fall into the fields regulated in the ASEAN Economic community. In the AEC Blueprint 2025 document, it states that seeking regional mechanisms to protect the assets of work and commercialization, including building schemes that help SMEs and the creative sector. That the competitive, innovative and dynamic character of ASEAN is to strengthen cooperation in the field of intellectual property right

The Mataatua Declaration on Cultural and Intellectual Property Rights of Indigenous People states that Indigenous Peoples in the world have the right to self-determination and in exercising these rights must be recognized as the exclusive owner of their cultural and intellectual property. In this declaration, it provides a number of recommendations both to indigenous peoples, to States and international bodies.

The United Nations Declaration on the Rights of Indigenous Peoples (UNDRIP) recognizes the right of indigenous peoples to carry out their cultural traditions and customary laws. This includes the right to protect, protect and develop both the habits that exist in the past, present and future cultures such as the historical and archaeological sites, artifacts, designs, ceremonies, traditional knowledge, art performances and literature. The Declaration states that the State must provide protection through effective mechanisms, which can be in the form of restitution, development of traditional societies by respecting their cultural, intellectual, religious and spiritual wealth without taking free, reasonable / fair information agreements or violating customary laws, traditions and customs. 
TCEs in Azerbaijan like music known as Mugham is an oral-professional branch, aşıq bardic music is folk-professional, and there are folk songs, work songs, lullabies, etc. are just folk music. In the creation of mugam music creation it is believed that there is a connection with God (Dessiatnitchenko, 2017). Another works and the most extensive folk art is carpet weaving. It makes its way into the daily lives of the people of Azerbaijan and turns into a symbol for the nation. Azerbaijanis and they are mainly involved in carpet weaving, while Armenians must learn to weave carpets from them (Taghiyeva, 2009).

Regulations on Traditional Cultural Expressions in Azerbaijan are regulated by separate laws. The title of the law is The Law of the Republic of Azerbaijan on Legal Protection of Azerbaijani Folklore Expressions. The law regulates the relationship between legal protection, utilization and preservation protection from the expression of national folklore as a component of cultural heritage as a special type of intellectual property. Azerbaijani, protect TCEs in non-IP system with Law on Legal Protection of Azerbaijani Folklore Expressions (Law No. 638-IVQD). Copyright law strictly stated that TCEs as public domain ruled in special law.

Kenya, Protection of TCEs both in IP System (Copyrights Law) and Non IP System (New York City Bar Association African Affairs Committee, 2016). TCEs not as "public domain", state it the owner means local and traditional communities. Prior informed consent for use and National government shall protect it from misuse and misappropriation.

The West African countries have realized that the Copyright Law cannot provide adequate protection against Traditional Cultural Expressions even though in the international realm there are efforts to expand the scope of the law. Consequently the West African Jurisdiction makes protective efforts through special legislation (New York City Bar Association African Affairs Committee, 2016).

The Constitution of the Republic of Indonesia in Article 28 I paragraph (3) states that: Cultural identity and traditional community rights are respected in line with the times and civilizations. Thus, the state 'recognizes' and 'respects' the existence of indigenous and tribal peoples, but with 4 (four) juridical requirements, namely:

as long as it still exists,

in accordance with the times and civilizations,

in accordance with the principles of the unitary state of the Republic of Indonesia, and

regulated in law.

The four conditions can be called constitutional requirements.

TCEs in Indonesia can be describes like music (angklung, gamelan), dance (Reog, Srimpi), storytelling (kancil dan timun mas) and so on. In the copyright law explain that "traditional cultural expression" includes one or a combination of the following forms of expression:

verbal textual, both oral and written, in the form of prose and poetry, in various themes and content of messages, which can be in the form of literary works or informative narratives;

music, including but not limited to vocal, instrumental or combination thereof;

motion, including but not limited to dancing;

theater, including but not limited to wayang performances and folk plays;

fine arts, both in two-dimensional and three-dimensional forms made from various materials such as leather, wood, bamboo, metal, stone, ceramics, paper, textiles, etc. or their combination; and traditional ceremonies.

TCEs in Indonesia are very rich and needs to be protected because there are so fragile to be claim like Batik to be claim by Adidas, Tempe by Thailand and so on (Setyaningtyas \& Kawuryan, 2016). So the regulation not to be used unlawfully needs to be done, one of which is through the defensive protection. That the meaning of defensive protection is a form of defensive protection that is carrying out preservation and preventive efforts to anticipate the existence of commercial and non-commercial abuse of traditional works. Traditional Knowledge is intellectual work in the field of knowledge and technology that contains elements of traditional heritage characteristics that are produced, developed and 
maintained by local communities or indigenous peoples. TCEs are intellectual works in the arts, including literary expressions that contain elements of traditional heritage characteristics that are produced, developed, and maintained by local communities or indigenous peoples.

Solutions to the protection of traditional knowledge in IPR law may be sought in terms of 'positive protection' and 'defensive protection'. Positive protection refers to the acquisition by the TK holders themselves of an IPR such as a patent or an alternative right provided in a sui generis system. Defensive protection refers to provisions adopted in the law or by the regulatory authorities to prevent IPR claims to knowledge, a cultural expression or a product being granted to unauthorised persons or organisations. Positive protection measures may also serve to provide defensive protection and vice versa. The distinction between the two, then, is not always clear-cut (Dutfield, 2003).

There are proposal for solution of TCEs used. WIPO draft "Domaine public payant", or "paying public domain," a fee is imposed for the use of works in the public domain. That regime applies is usually only composed of works the copyright of which has expired or in countries applying it to expressions of folklore. In some countries, only the commercial or for-profit exploitation of public domain material is subject to payment (World Intellectual Property Organization, 1985) or described as a "Use now, pay later" scheme (World Intellectual Property Organization, 2008). Unjust Enrichment Theory is a general equitable principle that no person should be allowed to profit at another's expense without making restitution for the reasonable value of any property, services, or other benefits that have been unfairly received and retained.

TCEs had seriously threatened by cultural erosion by using for product that leaves the value in it. However, the government actually did so that the violations continued. In these cases, it can be seen that the use of TCEs does not only discuss the reasons of interests or economic benefits, about the misuse of traditional culture which is used as an economically traded commodity (commodification and commercialization of culture), but there are a number of social, cultural, and spiritual elements contained in TCEs.

In particular, the protection of TCEs on the Intellectual Property system has a number of problems. Article 38 of the Law No. 28/2014 on Copyrights that state as "copyright holder" of TCEs. It should be the indigenous people who creator and the holder of the rights. Next paragraph, the appropriation of it regulated under government regulation, it should be ruled by legislation. Indirectly and ambiguously, the State recognizes TCEs in the Copyright regime. Whereas TCE is different from the copyright regime. Philosophically, the issuance of the Law on Copyright is based on the philosophy of Individualism. In addition, in the next paragraph, it is said that the use of TCEs must "pay attention" with value of TCEs. Content of the rule must be change accordance with that government "should" protect it. Not only just defensive protection i.e. in the paragraph 2 state preservation action. Misconception for it positions under copyright that is individual in nature that different with communal right. Then, in the derivative works of TCEs, as stipulated in Article 40 paragraph 1 letter o and q are original works. Unfortunately, in paragraph 2 there is no obligation to mention the owner of TCEs used in the derivative works.

In the Law No. 20/2016 on Trademarks and Geographical Indications Chapter XII, Abolition and Cancellation of Trademark Registration Article 72 paragraph 7 (c), abolition of registered Trademarks on the initiative of the Minister can be carried out if they "same or similar to" with TCEs, intangible cultural heritage, or names or logos that have been a hereditary tradition. The defensive protection that ruled in is diminished by government regulation Number 67 Tahun 2016 about Trademark Registration.

Then, the issue of protection authority, in the Law No. 23/2014 on Regional Government, which reduces the role of the State as the Copyright holder to become a concurrent central government affair in providing protection of IPRs of Traditional Communal communities. Julinda Idriaty stating that the regional government has not yet made a Regional Regulation on the protection of IPRs, especially TCEs to provide recommendations for the formation of Regional Regulations (Idriaty, 2015). However, the annex of the Law No. 23/2014 states that protection of TCEs becomes the affairs of the Central Government. It is very contradictory and inefficient if the problem of regional TCEs becomes the affairs of the central government because the regions know better and are closer to the problem of TCEs. It can lead to injustice for the region and traditional communities.

In "Ius Constituendum" as a sui generis law to protect against misuse of TCEs is the Draft of Law on 
Protection and Utilization of Intellectual Property Traditional Knowledge and Traditional Cultural Expression comes from The Regional Representative council. The draft strictly stipulated recognizes indigenous people as the holder/ beneficiary of the right. It states using of TCEs without permit can be entail civil, administrative and criminal liability. Unfortunately the draft law is not included in the national legislation program. This is an indicator that the state has not taken seriously the protection of the intellectual property of indigenous peoples.

Another requirement to use for commercialization is any benefit sharing that have to pay. The concept derives from that difference with "domaine public payant" scheme because TCEs is not public domain. There are remedies that should have done by clearly with restitution principle or unjust enrichment theory. Unfortunately, article about benefit sharing contract don't explain clearly that "sharing" will not harm for indigenous people. To prevent that situation, it can be added the district attorney as state lawyer to be consultant for making the contract.

The impact of the weak protection policy instruments on the intellectual property of traditional communities has led to increased exploration and exploitation of indigenous / traditional community assets. Due to the weak legal protection of the intellectual property (Roisah, 2017) of traditional indigenous peoples, what mostly happens is illegal exploitation by foreign parties. This was reinforced when the regulation of intellectual property which was later institutionalized in the TRIPs was under the umbrella of the World Trade Organization (WTO) which strengthened Intellectual Property Rights as the basic or core of the capitalism economy. For example, GATS does not provide for any recognition of indigenous rights or cultural identity (Robertson, 2006).

The absence of rules regarding the utilization of TCEs results in misuse and the commodification of traditional cultural products. The reason for protecting TCEs is based on the values of justice. It can be found in Pancasila as a view of the life of the Indonesian people that's explained in the precepts of it. Concludes that justice is the use of TCEs in order to maintain the values contained therein. Therefore, according to the perspective of the Dignity of Justice Theory, justice for the rights holders of the palaceowned work if based on the unjust enrichment theory, the entrepreneurs, that use should give Moral Rights and Economic Rights to the Sunanate Surakarta as the owner.

Legal renewal both in the legal system of intellectual property with the character of Indonesia and in the sui generis of the utilization of TCEs needs to be done immediately. so that it can harmonize with the Draft of Law on Traditional Knowledge and TCEs for the future Act as "Ius Constituendum".

\section{IV.CONCLUSION}

The end of discussion is suggestion for reconstruction of Law to protect TCEs. The Copyright Act article 38 is the State as the holder of "TCEs Right" not as "copyright holder" because it can be misconception. Another paragraph, the rule about utilization of TCEs not just government regulation but ruled by legislation. In the trademark and geographical indication Act that ministry can abolished trademark that infringement TCEs not just as "same of or similarity" but "consist of". Then in Law No. 23/2014 on the Regional Government have to change concurrent authority that regional government can be positively protect TCEs not only perform preservation. Based on the theory of legal development, unjust enrichment theory, the regulation on the use of TCEs can be done with regulations both in the IP System and Non IP system (Azerbaijan, Kenya). Utilization of TCEs Appreciation to the entities of the Sunanate Surakarta as the rights holders should be explicitly protected in a dignified manner. It is necessary to rebuild the rules/related to the use of TCEs that are spread in various laws. Reconstruction of the rules related to the use of TCEs is to try to put it back in dignity by harmonizing legislation related to the utilization of TCEs.

\section{REFERENCE}

Alting, H. (2010). Dinamika Hukum dalam Pengakuan dan Perlindungan Hak Masyarakat Hukum Adat Atas Tanah. Yogyakarta: Laksbang PRESSindo.

Andersen, M. J. (2010). Claiming The Glass Slipper:The Protection Of Folklore As Traditional Knowledge. Western Reserve Journal of Law, Technology \& the Internet, 1(2), 148-164. Retrieved from http://ip-medportal.net/sites/default/files/Claiming the Glass Slipper_The Protection of Folklore as Traditi.pdf

Dessiatnitchenko, P. (2017). Musical and Ontological Possibilities of Mugham Creativity in pre-Soviet, Soviet, and 
post-Soviet Azerbaijan (Department of Music University of Toronto). Retrieved from https:// tspace.library.utoronto.ca/bitstream/1807/80818/3/Dessiatnitchenko_

Dutfield, G. (2003). Protecting Traditional Knowledge and Folklore A review of Progress in Diplomacy and Policy Formulation. Retrieved from https://unctad.org/en/PublicationsLibrary/ictsd2003ipd1_en.pdf

Fimela. (2013). Makeup Etnik Ala Motif Batik, Cobain Yuk Cantik! Retrieved from Vemale.com website: https:// www.vemale.com/sariayu-putih-langsat/37391-makeup-etnik-ala-motif-batik-cobain-yuk-cantik-3.html.

Fuady, M. (2002). Doktrin-doktrin Modern Dalam Corporate Law Dan eksistensinya dalam hukum Indonesia. Bandung: Citra Aditya Bakti.

Goodwin, K. (2013). Protecting Architectural Forms as Traditional Cultural Expression? Why WIPO Should Go Back to the Drafting Table. Columbia Journal of Transnational Law, 51(2), 507-538. Retrieved from http:// blogs2.law.columbia.edu/jtl/protecting-architectural-forms-as-traditional-cultural-expression-why-wiposhould-go-back-to-the-drafting-table/

Hardie, M. (1998). The Bulun Bulun Case: John Bulun Bulun \& Anor v R \& T Textiles Pty Ltd". Indigenous Law Bulletin, 4(16). Retrieved from http://classic.austlii.edu.au/au/journals/IndigLawB/1998/87.html

Idriaty, J. (2015). Perlindungan Hukum Ekspresi Budaya Tradisional Oleh Negara Sebagai Pemegang Hak Cipta Kekayaan Intelektual Komunal Masyarakat Sulawesi Tenggara Dikaitkan Dengan Hak Ekonomi Berdasarkan Undang Undang Nomor 28 Tahun 2014 Tentang Hak Cipta (Program Magister (S2) Ilmu Hukum Fakultas Hukum Universitas Padjadjaran). Retrieved from http://pustaka.unpad.ac.id/wp-content/ uploads/2015/09/PERLINDUNGAN-HUKUM-EKSPRESI-BUDAYA-TRADISIONAL.pdf

Kuncoro, R. A. (2010). Perspektif Perbanyakan dan Dualisme Proteksi Hak Cipta: Studi Kasus Ukiran Jepara (Fakultas Hukum Program Pascasarjana Universitas Indonesia). Retrieved from http://lib.ui.ac.id/file? file=digital/2016-12/20369944-T37680-Retno Ardianti Koentjoro.pdf

Lee, M. J. (2015). Disney's 'Mulan' Headed For A Live-Action Adaptation. Retrieved from geeksofdoom.com website: https://geeksofdoom.com/2015/03/30/disney-mulan-live-action-adaptation

Lum-ho, W. (2013). Exploitation of Polynesian Spiritual Imagery in the Toy Industry. HOHONU, 11, 16-20. Retrieved from https:/hilo.hawaii.edu/campuscenter/hohonu/volumes/documents/ ExploitationofPolynesianSpiritualImageryintheToyIndustryWainohiaLum-ho.pdf

New York City Bar Association African Affairs Committee. (2016). Legal Framework for Protecting Traditional Cultural Expressions in West Africa. Retrieved from nycbar.org website: https://www2.nycbar.org/pdf/ report/uploads/20073038-ProtectingTraditionalCulturalExpressionsinWAfricaAFRICAN2222016.pdf

Nurtjahjo, H., \& Fuad, F. (2010). Legal Standing Kesatuan Masyarakat Hukum Adat dalam Berperkara di Mahkamah Konstitusi. Jakarta: Salemba Humanika.

Robertson, S. L. (2006). Globalisation, GATS and Trading in Education Services', published by the Centre for Globalisation, Education and Societies. Retrieved from susanleerobertson.files.wordpress.com website: https://susanleerobertson.files.wordpress.com/2009/10/2006-kallo-gats.pdf

Roisah, K. (2017). Legal Politics of Protection of Indonesian Traditional Cultural Expressions/Folklore. Diponegoro Law Review, 2(1), 185-202. Retrieved from https://doi.org/10.14710/dilrev.2.1.2017.185-202

Setyaningtyas, A. C., \& Kawuryan, E. S. (2016). Menjaga Ekspresi Budaya Tradisional Di Indonesia. Jurnal Ilmu Hukum Tambun Bungai, 1(2), 122-132. Retrieved from https://repository.unej.ac.id/bitstream/ handle/123456789/80183/Artikel Ayu 51-60.pdf?sequence=1

Taghiyeva, R. (2009). The Art Of Azerbaijani Carpet Weaving In The Context Of The Intercivilizational Dialog, Institute for Central Asian and Caucasian Studies. The Caucasus \& Globalization Geoculture, 3(2-3), 133146. Retrieved from https://cyberleninka.ru/article/n/the-art-of-azerbaijani-carpet-weaving-in-the-context-of -the-intercivilizational-dialog

Tama, W. H. (2017). Perlindungan Hukum A tas Simbol Tradisional Keraton Yogyakarta Dari Perspektif Hukum Merek (Universitas Islam Indonesia). Retrieved from https://dspace.uii.ac.id/bitstream/ handle/123456789/9056/TESIS_WIRA HARRI TAMA\%2C S.H..pdf?sequence=1\&isAllowed=y.

World Intellectual Property Organization. (1985). Model Provosion for National Laws on The Protection of Expression of Folklore Againts Illicit Exploitation and Other Prejudical Action. Retrieved from Wipo.int website: http://www.wipo.int/export/sites/www/tk/en/folklore/1982-folklore-model-provisions.pdf

World Intellectual Property Organization. (2008). The Protection of Traditional Cultural Expressions: Draft Gap Analysis. Retrieved from Wipo.int website: https://www.wipo.int/meetings/en/doc_details.jsp? doc_id=109673

Young, S. (2017). Maasai People Of East Africa Fighting Against Cultural Appropriation By Luxury Fashion Labels. Retrieved from Independent.co.uk website: https://www.independent.co.uk/life-style/fashion/maasai -people-cultural-appropriation-luxury-fashion-retailers-louis-vuitton-east-africa-intellectual-a7553701.html 